Short communication

\title{
Hygrophila madurensis (N.P. Balakr. \& Subram.) Karthik. \& Moorthy: An overlooked endemic species of Tamil Nadu, India
}

\author{
C. P. Muthupandi, R. Kottaimuthu ${ }^{\#, *}$ and K. Rajendran
}

\author{
Department of Botany, Thiagarajar College, Madurai-625 009, Tamil Nadu, India \\ ${ }^{\#}$ Current Affiliation: Department of Botany, Alagappa University, Karaikudi-630 003, Tamil Nadu, India \\ *Corresponding Author: kottaimuthu@yahoo.co.in \\ [Accepted: 11 April 2019] \\ [Cite as: Muthupandi CP, Kottaimuthu R \& Rajendran K (2019) Hygrophila madurensis (N.P. Balakr. \& \\ Subram.) Karthik. \& Moorthy: An overlooked endemic species of Tamil Nadu, India. Tropical Plant Research \\ 6(1): 115-118]
}

\section{INTRODUCTION}

The family Acanthaceae is positioned under the order Lamiales and belong to the core class Euasterids I of Core Eudicots (Chase \& Reveal 2009). According to the recent estimate (Karthikeyan et al. 2009) 593 Acanthaceae taxa (475 species and 118 varieties) are present in India. The genus Hygrophila R.Br. belongs to the tribe Ruellieae of family Acanthaceae (Scotland \& Vollessen 2000) and comprises about 100 species (Hu \& Daniel 2011). India is known to have 18 species (Karthikeyan et al. 2009, Sunojkumar \& Prasad 2014), of these H. madurensis and H. thymus are endemic to Tamil Nadu (Singh et al. 2015, Kottaimuthu et al. 2018).

During the course of our recent studies on the wetland plants of Madurai District, we have collected an interesting species of Acanthaceae that is characterized by distinctly pedicellate flowers, pedunculate cymes and linear-oblong capsules. Critical studies with pertinent literature; it is identified as Hygrophila madurensis (N. P. Balakr. \& Subram.) Karthik. \& Moorthy (Balakrishnan \& Subramanyam 1963, Balakrishnan 1988, Raja et al. 2015). A perusal of literature revealed that this species is listed as critically endangered and endemic to Tamil Nadu, found along the foothills of the Eastern Ghats (Balakrishnan 1988, Nayar 1996, Walter \& Gillett 1998, Reddy et al. 2006, Arisdason 2011). However, this species was not included in Acanthaceae of Eastern Ghats (Pullaiah et al. 2011). A detailed description, photographs, associated species and threat status are provided for easy identification and conservation of this little known endemic species.

Hygrophila madurensis (N. P. Balakr. \& Subram.) Karthik. \& Moorthy, Fl. Pl. India 22. 2009. Raja et al. in J.

Threat. Taxa 7(9): 7582. 2015.

Santapaua madurensis N.P. Balakr. \& Subram. in J. Indian Bot. Soc. 42: 411. 1963; G. R. Kumari in A. N. Henry, G. R. Kumari \& V. Chithra, Fl. Tamil Nadu, Ind., Ser I: Analysis 2: 160. 1987; N. P. Balakr. in Red Data Book Indian Pl. 2: 7. 1988.

(Fig. 1)

Herbs, 10-35 cm high; branchlets decumbent, arising from base; stems quadrangular, swollen at nodes. Leaves opposite, decussate, thin, membranous, glabrous, lanceolate or oblong-oblanceolate, base cuneate, margin minutely crenulate, acute or subacute at apex, lateral nerves 5-7 pairs, prominent below; rhaphides scattered on upper surface, petioles $2-3 \mathrm{~mm}$ long. Flowers in axillary open dichasial cymes becoming sympodial and unilateral, usually shorter than leaves; primary peduncle $c a .5 \mathrm{~mm}$ long; internodes $c a .3 \mathrm{~mm}$ long; bracts linear, acute, 2-5 mm long; pedicels ca. $1 \mathrm{~mm}$ long. Calyx 5 lobes, free, sub equal, linear, acute, 4-5×1 mm. Corolla purple, bi-lipped, 5-10 mm long; tube funnel-shaped, broad, pubescent inside; upper lip bifid, emarginate, lobes rounded; lower lip trifid, lobes obtuse, rounded. Stamens 4, didynamous; filaments linear, filiform, glabrous, 2-4 mm long; anthers oblong, ellipsoid, 1.0-1.3 mm long. Ovary pubescent, oblong or oblong-ellipsoid, $2 \mathrm{~mm}$ long, 2-celled with many ovules; style linear, 4mm long, hairy; stigma simple. Capsules linear-oblong, flat, sessile, 6-8 mm long; seeds bearing throughout the length of the capsule; retinacula minute, conical, straight, slender. Seeds 20-40, small, ellipsoid or ovoid-ellipsoid, compressed, 107.5-108.6 × 163.24$164.34 \mu \mathrm{m}$, glandular puberulous, when wet; hairs 24-27.61 $\mu \mathrm{m}$ long

Flowering \& Fruiting: November to March. 

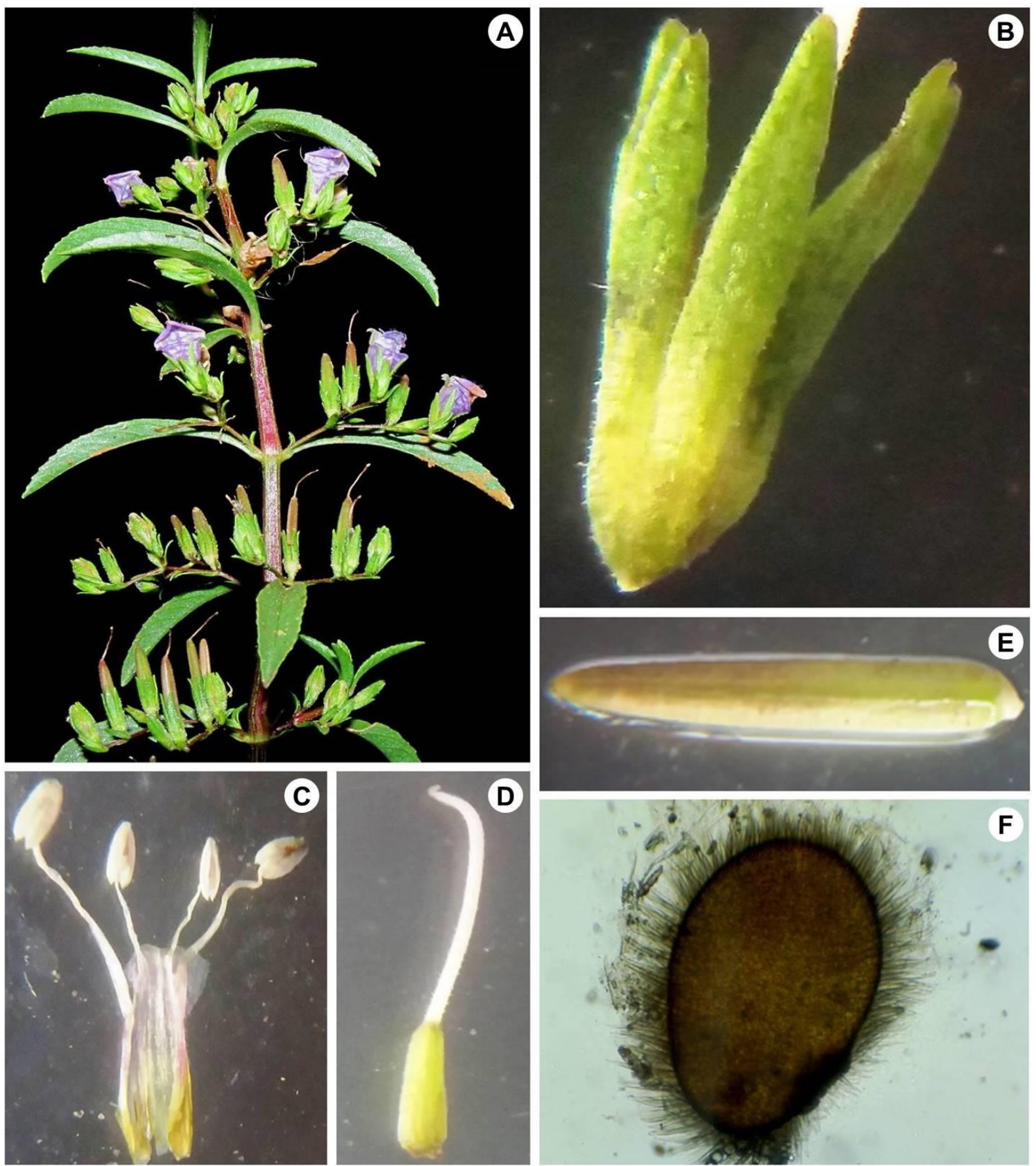

Figure 1. Hygrophila madurensis (N. P. Balakr. \& Subram.) Karthik. \& Moorthy: A, Flowering twig; B, Calyx; C, Stamens; D, Ovary; E, Capsule; F, Seed close up.

Specimens examined: INDIA, Tamil Nadu, Madurai Dis., 08.03.2018, Sakkimangalam, Ayyankulam and C. P. Muthupandi 65 (Thiagarajar College Herbarium); 10.03.2018, C. P. Muthupandi \& R. Kottaimuthu 112 (Thiagarajar College Herbarium).

Distribution: INDIA (Tamil Nadu), Endemic.

Biotic Association: A single population of about 20 individuals were observed in the present locality and it is often associated with the following species, Bergia ammannioides, Ludwigia perennis, Ammannia baccifera, Echinochloa colona, Vahlia dichotoma, Lindernia parviflora, Scoparia dulcis, Chloris barbata, Mollugo pentaphylla, Desmodium triflorum, Fimbristylis sp., Leptochloa sp., Ludwigia hyssopifolia, Prosopis juliflora, Coldenia procumbens, Euphorbia thymifolia, Cyanodon dactylon, Nothosaerva brachiata, Aeschynomene indica, Sphaeranthus indicus, Heliotropium indicum, Cyperus difformis, Phyllanthus maderaspatensis, Fimbristylis milliacea, Corchorus fascicularis, Epaltes divaricata and Eclipta alba.

Nomenclature: Hygrophila madurensis was originally described by Balakrishnan \& Subramanyam (1963) under the genus Santapaua as Santapaua madurensis. However, later authors (Heine $1962 \&$ 1971, Cramer www.tropicalplantresearch.com 
1989 \& 1998, Sidwell 1999), agreed to follow the broader generic concept and placed Adenosma, Asteracantha, Cardanthera, Hemiadelphis, Nomaphila, Plaesianthera and Synnema under Hygrophila and this was accepted in the classification of Acanthaceae (Scotland \& Vollessen 2000). Following this broader concept, Karthikeyan et al. (2009) reduced the genus Santapaua into Hygrophila.

The type specimen was collected by K. Subramanyam near Nallakulam in Alagar Hills. Later Ravikumar (1993) relocated this species from the type locality and there after it was also collected by Arulappan in Narthamalai in Pudukkottai district (Balakrishnan 1988). Now the population becomes endangered due to narrow distribution and over-grazing in the natural habitat (Reddy et al. 2006).

\section{CONCLUSION}

The range extension of endemic species will provide a wealth of research opportunities for ecologists and conservation biologists in understanding the key drivers of endemism (Kottaimuthu 2017, Kottaimuthu et al. 2018). Hitherto this species is known only to very few locations. Hence, periodical assessment in all the known localities and searching for other sites of occurrence in Tamil Nadu is strongly recommended. Moreover, all the known population is prone to maximum human interference hence urgent conservation measures are recommended for $H$. madurensis.

\section{ACKNOWLEDGEMENTS}

We would like to thank the Management and Principal, Thiagarajar College, Madurai, for the help provided during the study. We are thankful to retired Dr. G. V. S. Murthy, Scientist G, Botanical Survey of India, Southern Regional Centre, Coimbatore for granting permission to consult the herbarium and library.

\section{REFERENCES}

Arisdason W (2011) Hygrophila madurensis. In: IUCN 2011. IUCN Red List of Threatened Species. Version 2011.2. <www.iucnredlist.org>. Downloaded on 10 April 2018.

Balakrishnan NP \& Subramanyam K (1963) A new genus of Acanthaceae from Peninsular India. Journal of Indian Botanical Society 42: 411-415.

Balakrishnan NP (1988) Santapaua madurensis. In: Nayar MP \& Sastry ARK (eds) Red Data Book of Indian Plants, Vol. II. Botanical Survey of India, Howrah.

Chase MW \& Reveal J (2009) A phylogenetic classification of the land plants to accompany APG III. Botanical Journal of Linnaean Society 161: 122-127.

Cramer L (1989) The Hygrophila complex (Acanthaceae) in India and Ceylon. Nordic Journal of Botany 9(3): 261-263.

Cramer L (1998) Acanthaceae. In: Dassanayakae MD \& Clayton WT (eds) A Revised Handbook to the Flora of Ceylon, Vol. X. Amerind Pub. Co. Pvt. Ltd., New Delhi.

Heine H (1962) Notes on Some West African Acanthaceae: The reduction of the genus Asteracantha Ness to Hygrophila R. Br. Kew Bulletin 16: 171-173.

Heine H (1971) Notes sur Les Acanthacees Africaines: Hygrophila R.Br. Adansonia 11(4): 656-659.

Hu J \& Daniel TF (2011) Acanthaceae: Hygrophila. In: Wu ZY, Raven PH \& Hong DY (eds) Flora of China, Vol. 19. Missouri Botanical Garden Press, St. Louis, USA.

Karthikeyan, S, Sanjappa M \& Moorthy S (2009) Flowering Plants of India - Dicotyledons (Acanthaceae Avicenniaceae). Botanical Survey of India, Kolkata.

Kottaimuthu R (2017) Crotalaria heyneana (Fabaceae) in Eastern Ghats of India: A new distributional record. Journal of Economic and Taxonomic Botany 40(3-4): 156-157.

Kottaimuthu R, Muthupandi CP \& Rajendran K (2018) Ecbolium viride (Forssk.) Alston var. chandrasekariana Remadevi \& Binojk. (Ruellieae: Acanthaceae): A new report for Tamil Nadu. NeBIO 9(2): 215-218.

Nayar MP (1996) Hot spots of Endemic Plants of India, Nepal \& Bhutan. TBGRI, Thiruvananthapuram.

Pullaiah T, Rani SS \& Karuppusamy S (2011) Flora of Eastern Ghats, Vol. IV. Regency Publications, New Delhi.

Raja P, Soosairaj S, Dhatchanamoorthy N \& Kala A (2015) A new distribution record for the critically endangered Madura swamp weed Hygrophila madurensis (N.P. Balakr. \& Subr.) Karthik \& Moorthy (Acanthaceae). Journal of Threatened Taxa 7(9): 7581-7583.

Ravikumar K (1993) Systematic Studies on the Dicotyledonous Plants of Madurai District, Tamil Nadu, India, (Ph.D. Thesis). Bharathiar University, Coimbatore. 
Reddy CS, Brahmam M \& Raju VS (2006) Conservation prioritization of endemic plants of Eastern Ghats, India. Journal of Economic and Taxonomic Botany 30: 755-772.

Scotland RW \& Vollesen K (2000) Classification of Acanthaceae. Kew Bulletin 55(3): 513-589.

Sidwell K (1999) The taxonomic position of the Sri Lankan species Brillantaisia thwaitesii (T. Anderson) L. H. Cramer. (Acanthaceae). Kew Bulletin 54(1): 215-219.

Singh P, Karthigeyan K, Lakshminarasimhan P \& Dash SS (2015) Endemic Vascular Plants of India. Botanical Survey of India, Kolkatta.

Sunojkumar P \& Prasad MG (2014) Taxonomic reinstatement of an endemic Hygrophila (Acanthaceae) subsequent to its rediscovery after 180 years from India. Rheedea 24(1): 12-15.

Walter KS \& Gillett HJ (1998) IUCN Red List of Threatened Plants. Compiled by the World Conservation Monitoring Centre. IUCN, Gland. 